\title{
5. 放射性医薬品
}

横 山陽・藤 林 靖 久*

京都大学薬学部放射性薬品化学講座

*京都大学薬学部遺伝子薬品学講座

〔誌上講座〕核医学検査技術学

1. 核医学検查機器の最近の進歩

2. ガンマカメラ装置の撮像原理

3. SPECT $の$ 再構成

4. PET 装置の撮像原理

5. 放射性医薬品

6. 核医学イメージング理論

7. 核医学検查の臨床

8. PET - SPECT の臨床

9. 核医学撮像装置の $\mathrm{QC} \cdot \mathrm{QA}$

10. 試料測定技術の現状と将来

11. 医用放射線物質の安全管理

\section{1.はじめに}

インビボ核医学検査（以下，核医学検查）は，放射線 を用いて人体から画像を得ることにより診断するという 点でレントダン撮影，X線 CT や骨塩定量装置などの放 射線検查と混同されやすい。しかしながらレントゲン撮 影やX線 CT，骨塩定量装置が放射線と人体との相互作 用を利用する，すなわち体外におかれた線源から出され る一定の放射線が人体を透過するときの吸収変化を検出 するのに対し，核医学検查の特幑は放射性核種で標識さ れた医薬品（放射性医薬品＝線源）を体内に投与し，そ の標的組織への移行性や結合量を医薬品から放出される 放射線を指標として体外へ検出することにある。したが って核医学検查は医薬品と人体との相互作用を検出・画 像化する点で上記の他の放射線検査とは原理的に異なる. 核医学検査で得られる画像の意味は用いられる放射性医 薬品によってすべてが決定されるといっても過言ではな w.

放射性医薬品は短寿命医楽品であるため標識操作や品
質管理が診療現場において夷施可能であることが必須と なる.このことが放射性医薬品に関する知識や経験を有 する医療従事者の育成が望まれる理由であり，日常的に 実施される核医学検查が十分に意義あるものとなる上で 最も重要なポイントといえる，本稿では，放射性医薬品 の諸性質について現在利用されているあるいは開発段階 にあるものを例にあげながら基本から概説する。

\section{2. 核医学に用いられる放射性核種}

放射能とは，原子核の崩壊に伴って核外へ $\alpha, \beta, \gamma$, $\beta^{+}$線などの放射線を放出する性質をいい, 放射能を有す る核種を放射性核種と呼ぶ。 $\gamma$ 線はX線や光と同じ電磁 波であり，物質透過性が非常に高く体外検出が容易で生 体に与える影響も少ない.また $\beta^{+}$線は，原子核から放出 されるとすぐに周辺の電子と結合し消滅するとともにそ れらの質量に応じた 2 本の消隇放射線と呼ばれる電磁波 を放出する.それに対し， $\alpha$ 線， $\beta$ 線はそれぞれへリウム 原子核，電子であり，生体に投与した場合物質透過性が 低いため体外計測がむずかしいのみならず大きな影響を 引き起こす (Fig. 1). したがって放射性医薬品の標識に

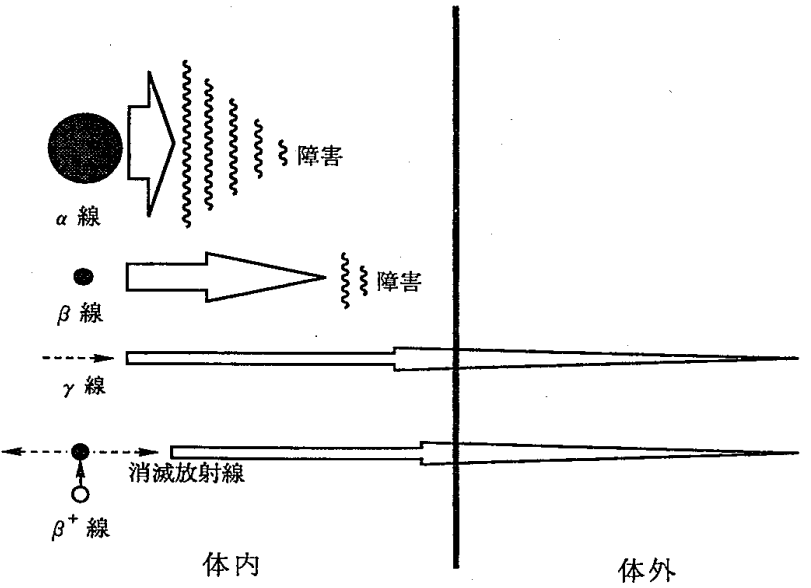

Fig. 1 放射線の種類と特徵 
Table 1 インビボ用放射性医薬品の標識核種 承認を受け現在市販されているもの

\begin{tabular}{llll}
\hline \hline \multicolumn{1}{c}{ 核種 } & 半隇期 & 崩壊形式 & $\begin{array}{c}\text { 主要 } \gamma \text { エネルギー } \\
(\mathrm{keV})\end{array}$ \\
\hline $\mathrm{Ga}-67$ & $78.2 \mathrm{hr}$ & $\mathrm{EC}$ & $93,185,300$ \\
$\mathrm{Tc}-99 \mathrm{~m}$ & $6.01 \mathrm{hr}$ & $\mathrm{IT}$ & 140 \\
$\mathrm{I}-131$ & $8.02 \mathrm{~d}$ & $\beta$ & 365 \\
$\mathrm{I}-123$ & $13.2 \mathrm{~h}$ & $\mathrm{EC}$ & 159 \\
$\mathrm{Xe}-133$ & $5.24 \mathrm{~d}$ & $\beta$ & 81 \\
$\mathrm{~T} 1-201$ & $72.9 \mathrm{~h}$ & $\mathrm{EC}$ & $69-80,135,167$ \\
$\mathrm{Cr}-51$ & $27.7 \mathrm{~d}$ & $\mathrm{EC}$ & 320 \\
$\mathrm{Fe}-59$ & $44.5 \mathrm{~d}$ & $\beta^{+}, \mathrm{EC}$ & 1099,1292 \\
$\mathrm{Co}-57$ & $272 \mathrm{~d}$ & $\mathrm{EC}$ & 122 \\
$\mathrm{Co}-58$ & $70.8 \mathrm{~d}$ & $\beta^{+}, \mathrm{EC}$ & 511,811 \\
$\mathrm{Kr}-81 \mathrm{~m}$ & $13 \mathrm{~s}$ & $\mathrm{IT}$ & 190 \\
$\mathrm{In}-111$ & $2.81 \mathrm{~d}$ & $\mathrm{EC}$ & 171,245 \\
\hline
\end{tabular}

院内サイクロトロンで製造されているもの

\begin{tabular}{llll}
\hline \hline $\mathrm{C}-11$ & $20.39 \mathrm{~m}$ & $\beta^{+}, \mathrm{EC}$ & 511 \\
$\mathrm{~N}-13$ & $9.965 \mathrm{~m}$ & $\beta^{+}$ & 511 \\
$\mathrm{O}-15$ & $2.037 \mathrm{~m}$ & $\beta^{+}, \mathrm{EC}$ & 511 \\
$\mathrm{~F}-18$ & $109.8 \mathrm{~m}$ & $\beta^{+}, \mathrm{EC}$ & 511 \\
\hline
\end{tabular}

用いられる放射性核種は，放射能を体外から検出でき， かつ患者の被曝を他の放射線検査と同程度あるいはそれ 以下に抑えるため，(a)低エネルギー $\gamma$ 線 $(100-200 \mathrm{keV})$ あるいはポジトロン $\left(\beta^{+}\right)$のみを放出し，(b) $\alpha$ および $\beta^{-}$ 線を放出せず，(c)短半減期（数分〜数日）であることが 要求される。

現在法令（放射性医薬品製造規則 ${ }^{1}$ ) により放射性医薬 品核種として指定されている放射性核種は約 60 種類ある が, 実際に薬事法に基づいて承認を取得し市販されてい るインビボ用放射性医楽品の標識核種は Table 1 上段の と扔りである な時間を確保し得る半減期を持つものであり, アイソト 一プ協会を通じて使用時に購入される。また，超短半減 期 ( 2 〜10分) のため病院内サイクロトロンにより製造 される放射性核種として Table 1 下段にあげたものが 用いられている31.

ポジトロン核種が 2 本の消滅放射線（電磁波＝光子） を放出するのに対して, $\gamma$ 線核種をシングルフォトン $(1$ 本の光子）核種とも呼ぶ.

\section{3. 放射性核種の製造}

医療現場での放射性核種製造は，現在のところ病院内
サイクロトロンを有する少数の施設に限られており大多 数の医療従事者にとって直面する問題とはならないであ ろう。しかしながら放射性核種の製造原理を知ることは そこから発生する放射線の特性を理解し無用な被曝を避 ける上で意味がある．また広く利用されているジェネレ 一夕も広義に解釈すれば放射性核種の製造といえる。

\section{1 核反応を利用した製造}

原子核は，電荷をもたない中性子と，質量はほとんど 同じで正電荷を有する陽子とがあつまって構成されてい る. 原子の化学的性質を決定する陽子の数を原子番号 (Z)，陽子と中性子を合わせた粒子数を質量数 (A) と よび，原子番号が同じで質量数の異なる原子を同位体と よぶ.

原子核に中性子，陽子，重陽子などの粒子を一定の速 度で衝突させると粒子は核内に取り込まれ別種の粒子を 放出して異なった原子核に変わる。これを核反応という。 放射性核種の製造においては中性子源としては原子炉が， 陽子・重陽子などの荷電粒子源としてはサイクロトロン が主に用いられる。一般に中性子を衝突させた場合には 中性子過多の原子核が，陽子等の正電荷を有する粒子を 衝突させた場合には陽子過多の原子核が生成する，原子 核が安定でいるためには原子核の質量に応じて適当な中 性子対陽子比をとる必要があり，中性子過多の原子核は 電子 ( $\beta$ 線)を放出して中性子を陽子に, 陽子過多の原子 核は核外の電子を取り込む（電子捕獲）かあるいは陽電 子（ポジトロン）を放出して陽子を中性子に変化させ安 定化する．したがって，原子炉で製造された放射性核種 は $\beta$ 線放出核種が多く, サイクロトロンで製造された核 種は電子捕獲核種あるいはポジトロン核種が多い。電子 捕獲核種は電子を核内に取り込んだ際に $\gamma$ 線を放出す るため核医学利用に都合のよい核種であることから，ポ ジトロン核医学の普及化ともあわせて最近では陽子過剩 核種が望まれるようになってきつつある。

Fig. $2^{4)}$ に安定核種と少数の放射性核種の原子番号と 質量数とをプロットしたものを示す。この曲線より下側 $に \beta$ 線放出核種が，上側に電子捕獲あるいはポジトロン 核種が分布する。

\section{2 核分裂反応を利用した製造}

ウランのような重い原子核に中性子を衝突させ人工的 に核分裂させることにより 2 個の異なる原子核を作る方 法である。核分裂は非対称的に起きることが多く，ウラ ン-235の場合主として質量数90〜100と130〜140の原子 核が生成する. 生成された核種はいずれも中性子過多で あり $\beta$ 線放出核種となる。 


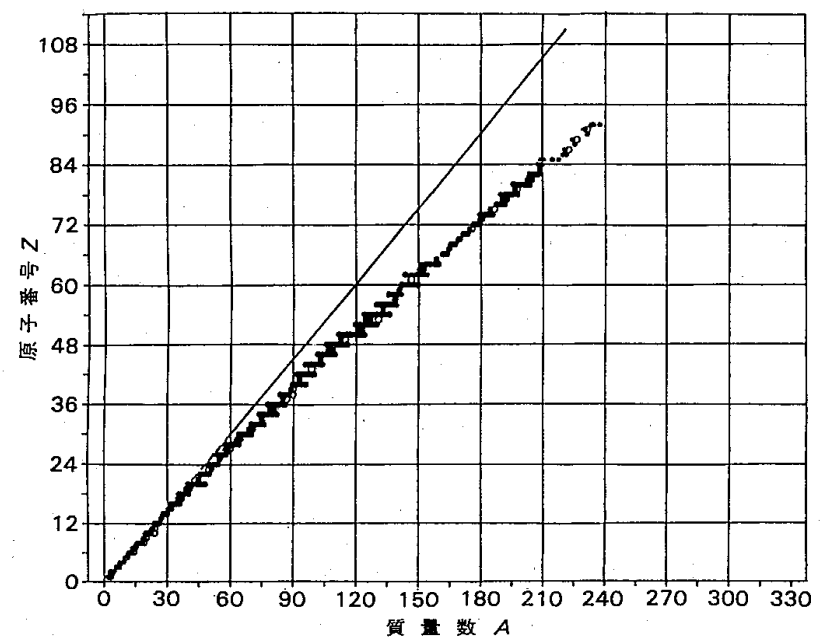

Fig. 2 岀定核種の原子番号と質量数

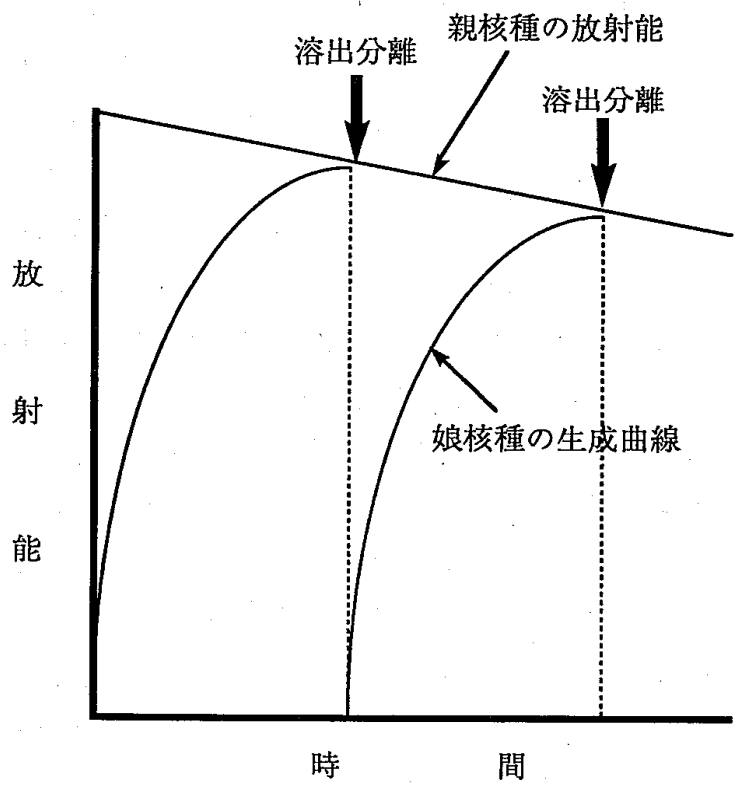

Fig.3 シェネレータの原理図

\section{3 ジェネレータ}

ある放射性核種（親核種）から生成した娘核種がさら に放射能を有しかつその半減期が親核種に比較して十分 に短い場合，娘核種はある時間経過後には生成量と崩壊 量とが等しい値となった定常状態となる。これを放射平 衡とよぶ.このような状態から娘核種を選択的に分離し 定期的に娘核種を放射性核種として利用できるようにし たものがジェネレータ（Fig. 3) である，基本的には，親 核種を結合させたカラムを一定時間放置し生成した娘核 種のみを水溶液あるいはガスで溶出するシステムが一般 的である.本邦において日常臨床に用いることのできる ジェネレータ核種には, Tc $99 \mathrm{~m}, \mathrm{Kr}-81 \mathrm{~m}$ がある。その 他，過去に用いられていたもの，外国に沶いて利用され
Table 2 ジェネレータとして用いられる親，娘核種

\begin{tabular}{llcc}
\hline \hline 親核種 & 娘核種 & 娘核種の半減期 & 娘核種の崩壊形式 \\
\hline $\mathrm{Mo}^{-99}$ & $\mathrm{Tc}-99 \mathrm{~m}$ & $6.02 \mathrm{~h}$ & $\mathrm{IT}$ \\
$\mathrm{Rb}-81$ & $\mathrm{Kr}-81 \mathrm{~m}$ & $13.0 \mathrm{~s}$ & $\mathrm{IT}$ \\
$\mathrm{Sn}-113$ & $\mathrm{In}-113 \mathrm{~m}$ & $99.5 \mathrm{~m}$ & $\mathrm{IT}$ \\
$\mathrm{Zn}-62$ & $\mathrm{Cu}-62$ & $9.73 \mathrm{~m}$ & $\beta^{+}, \mathrm{EC}$ \\
$\mathrm{Ge}-68$ & $\mathrm{Ga}-68$ & $68.1 \mathrm{~m}$ & $\beta^{+}, \mathrm{EC}$ \\
$\mathrm{Os}-119$ & $\mathrm{Ir}-119 \mathrm{~m}$ & $4.9 \mathrm{~s}$ & $\mathrm{IT}$ \\
$\mathrm{Hg}-195$ & $\mathrm{Au}-195 \mathrm{~m}$ & $30.6 \mathrm{~s}$ & $\mathrm{IT}$ \\
\hline
\end{tabular}

ているもの，研究レベルで臨床使用され今後に期待が持 てるもの等を Table 2 に挙げる.

市販のジェネレータは製薬会社によって製造され，溶 出してきた液体そのものが注射剤としての承認を受けて いる.したがって取扱に詰りがなければ親核種の混在や 細菌污染などは起きない.しかしながらジェネレータが おかれている環境は清潔区域でないことも多くそのよう な環境で数日から数週間連続して使用されることを考え ればその取扱には十分な注意が必要であり，放射能の検 定，無菌性の検定など必要に応じて実施できる体制が望 ましい.

\section{4. 放射性医薬品各論}

前述したように，核医学検査は放射性医薬品と人体と の相互作用によって生じる放射能分布の変化を検出しよ うとするものである，ここでは放射性医楽品が開発され てきた過程で徐々に対象を広範囲化し複雑な診断をこな せるようになった歴史をふまえて個々の放射性医薬品を 紹介する。

\section{1 血液分布}

血清アルブミンは血墏中に多く存在し血管外への漏出 は非常に遅いためその標識体は血漿分布を示し循環血液 量や心拍出量測定, 心プールシンチグラフィーに用いら れる。これは血液中に安定に存在するというアルブミン の生理的な性質を利用したものであるしたがって標識 はアルブミンの状態を可能なかぎり変化させない方法で 行われなければならない.アルブミンは元来金属結合夕 ンパクでもあり還元型 Tc を結合することができるため 還元剤とアルブミンを含んだ標識キットを用い使用時に ジェネレータから得られた Tc-99m 溶液によって標識 ができる、最近，強固な金属結合部位を導入したアルブ ミン誘導体を用いた Tc-99m 標識アルブミン $(\mathrm{Tc}-99 \mathrm{~m}-$ HSA-D，Fig.4）が開発され市販されている。これは直 接標識したものよりも血液中安定性に優れ正確な血㢡分 


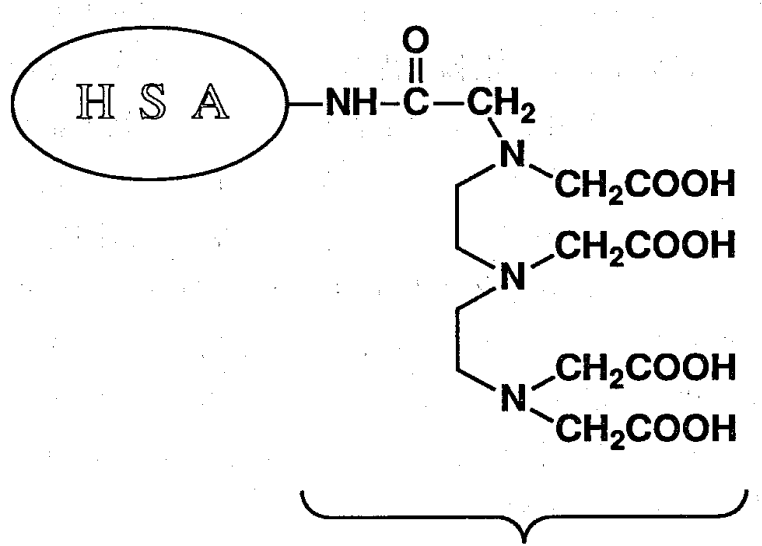

Metal binding site

Fig. 4 HSA-D の構造

布データが得られるものである。初期には I-131をアル ブミンのチロシン，ヒスチジン残基に共有結合させた標 識アルブミンが用いられていたが，I-131の出す $\beta$ 線に よる被曝と半減期の長さから最近ではあまり利用されな い.

これとは別に赤血球を標識する方法がある。最初, $\mathrm{Cr}$ $-51-\mathrm{CrO}_{4}{ }^{2-}$ が赤血球膜を透過した後細胞内でへモグロ ビン中のシステイン残基のチオールによって容易に還元 を受け滞留型の $\mathrm{Cr}^{3+}$ 変化することが見いだされたこ とから $\mathrm{Cr}-51$ 標識赤血球が用いられるようになった. $\mathrm{Cr}-$ 51による赤血球標識は非常に緩和に進行するため循環血 液量測定のみならず赤血球寿命測定にも用いられる。Cr -51標識の原理は画像診断に適した Tc- $99 \mathrm{~m}$ による赤血 球標識にも利用されている。 $\mathrm{Tc}-99 \mathrm{~m}-\mathrm{TcO}_{4}{ }^{-}$は $\mathrm{CrO}_{4}{ }^{2-}$ と同様容易に赤血球細胞膜を透過するが細胞内還元を受 けるためにはあらかじめ還元剤を人為的に加えられなけ ればならない.そこで $\mathrm{Sn}(\mathrm{II})$-ピロリン酸(骨シンチ製剤 キット・後述）を還元剤としてあらかじめ赤血球に加え る方法がとられる．標識法としては患者に Sn (II) -ピロ リン酸と Tc $-99 \mathrm{~m}$ を順次投与して行う in vivo 法と採取 してきた血液を用いて体外で行う in vitro 法とがあり前 者は簡便性に優れ後者は定量性に優れる特徵があるが, 現在のところ本邦では in vivo 法のみが承認されている.

\section{2 肺}

$\mathrm{Xe}-133, \mathrm{Kr}-81 \mathrm{~m}$ などの不活性ガスは生体との相互作 用がほとんどないため吸気とともに投与され肺換気能測

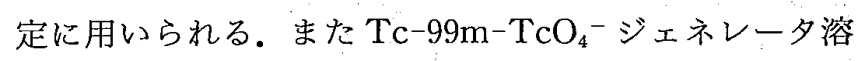
出液をテクネガス発生装置でガス化（微粒子化）したも のも用いられる．Tc-ガスは吸入後肺胞に吸着するため 不活性ガスとは異なり肺からの洗い出しはみられない.
Tc-99m-大凝集人血清アルブミン (MAA) は毛細血管よ りも大きい粒子径を有するため静脈投与されると最初に 通過する肺の毛細血管に血流分布に応じて捕捉されるこ とから肺血流診断に用いられる。

\section{3 甲 状 腺}

甲状腺はヨウ素アニオンを甲状腺ホルモン合成基質と して大量に摄取する組織である。放射性ヨウ素をヨウ化 ナトリウムとして経口投与すると速やかに体内に吸収さ れ甲状腺に摂取される．放射性ヨウ素は甲状腺内でチ口 シンと結合し $\mathrm{T} 3, \mathrm{~T} 4$ となりサイログロブリンとして蓄 積される。したがって放射性ヨウ素の甲状腺摂取率は甲 状腺機能診断に重要な指針を与える. 放射性ヨウ素とし ては I-131が用いられてきたが最近放射線の性質に優れ る I-123を大量製造することが可能となり診断目的には もっぱら I-123 が用いられるようになっている.一方，I -131 は $\beta$ 線による細胞障害性を利用して甲状腺ガンゃ 甲状腺機能充進症の治療に用いられ，2核種の使い分け が明確になってきている。

$\mathrm{Tc}-99 \mathrm{~m}-\mathrm{TcO}_{4}-$ も 1 価アニオンであり偽基質として 甲状腺に取り込まれることから放射性ヨウ素と同様甲状 腺機能診断に用いられる。

\section{4 骨・骨髄}

骨はりン酸カルシウムからなり，カルシウムやその同 族元素であるストロンチウムのみでなく Tc-99m リン 酸誘導体も集積することが知られている.さらに炎症, 腫場，骨折部などは活発な骨代謝が行われているため陽 性に描出される。臨床には Tc-99m-ピロリン酸, Tc99m-メチレンニリン酸 (MDP), Tc-99m-メタン-1-ヒ ドロキシージリン酸（MHDP）など（Fig.5）が用いられ る.カルシウムやストロンチウムの放射性核種は臨床利 用に適当でないため用いられなくなっている.

骨髄造血機能診断には鉄と類似した造血細胞集積を示 す In-111- $\mathrm{InCl}_{3}$ が用いられる。

\section{5 肝 臓}

肝臓は様々な機能を有する組織であるが，放射性医薬 品としては肝臟の持つ 3 種の異物・老廃物処理機能を利 用して肝臟選択性を得ている。

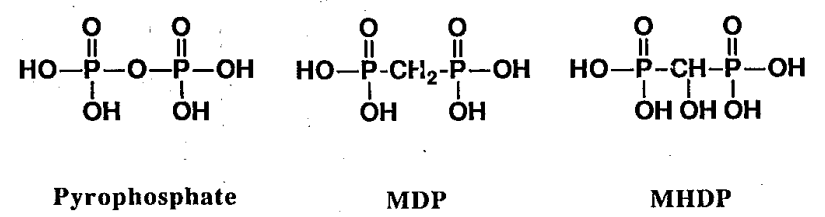

Fig. 5 リン酸誘導体の構造 


\section{5 .1 不溶性異物処理}

肝臓実質の15\%を占める肝網内系（特に Kupffer 細 胞）は血液中の不溶性異物を領食する。適当な大きさの 放射性コロイド粒子を静脈投与するとそれらは網内系細 胞分布ならびに血流分布にしたがって速やかに肝臓に集 積する. 網内系細胞に取り込まれた放射性コロイドは非 常にゆっくりと代謝されるため実際的な時間内で分布は 変化しない.これにより肝臓の形態学的診断と共に肝血 流評価も可能である．放射性コロイドとしては $\mathrm{Au}-198-$ コロイドがあったが，コロイドとしての優秀性にも関わ らず放射能が好ましくないため現在では Tc-99m-スズ コロイドや Tc-99m-フチン酸が汎用されている.前者は 粒子径0.4〜 $5 \mu \mathrm{m}$ のコロイドである. 後者はそれ自体コ ロイドではないが生体内に投与されると血液中のカルシ ウムと速やかに反応してコロイドを形成し肝蔵に集積す るものである。これらのコロイド製剤は脾臓診断にも用 いられる。

\section{5 .2 薬物・色素処理}

肝実質細胞はある種の薬物や色素を撖取し胆汁中へ排 泄することから，胆汁排泄性薬物あるいは色素の放射能 標識体が用いられる。この種の放射性医薬品は，コロイ<smiles></smiles>

PHMT

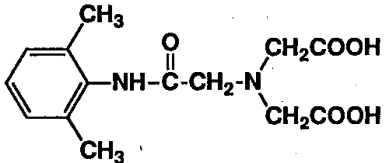

HIDA
Fig. 6 肝臟彰断薬の構造

ドとは異なり肝蔵へ集積した後, 速やかに胆汁として胆 霬・胆道を経て十二指腸へ排泄される。したがって経時 的撮影によって肝蔵, 胆道系診断ができる. 初期には口 ーズベンガル，ブロモスルフォフタレインといった色素 の I-131 標識体が用いられていたが, 現在では同様の挙 動をする Tc-99m 錯体として Tc-99m-N-(ジメチルフ エニルカルバモイルメチル)イミノ二酢酸 (HIDA) およ び Tc-99m-ピリドキシル-5-メチルトリプトファン (PHMT) などが開発され広く用いられている.これらの 構造を Fig. 6 に示す。

\subsection{3 アシアロ糖タンパク処理}

糖タンパクは不要になると酸性糖鎖末端のシアル酸が 除去されガラクトース残基が露出したアシアロ糖タンパ ク（アは「ない」の意味をもつ接頭語, したがって「ア シアロ」は「シアル酸基がない」の意）となる，肝実質 細胞表面にはアシアロ糖タンパクのガラクトース残基を 認識・結合し肝細胞内に取り込むレセプタータンパクが 存在する.取り込まれたアシアロ糖タンパクーレセプター 結合体は細胞内でライソゾーム酵素によって分解される. アシアロ糖タンパクレセプターは肝障害の程度に応じて 鋭敏に減少することから定量的肝細胞機能診断ができる。 このレセプターに対して親和性を有するタンパクとして ガラクトシル人血清アルブミン (Fig. 7) が合成され，さ

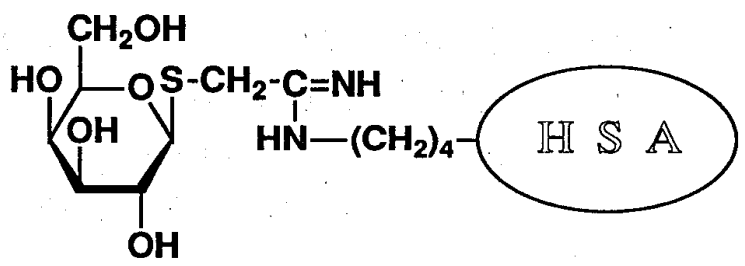

Fig. 7 NGA の構造
Tc-99m-DTPA In-111-DTPA

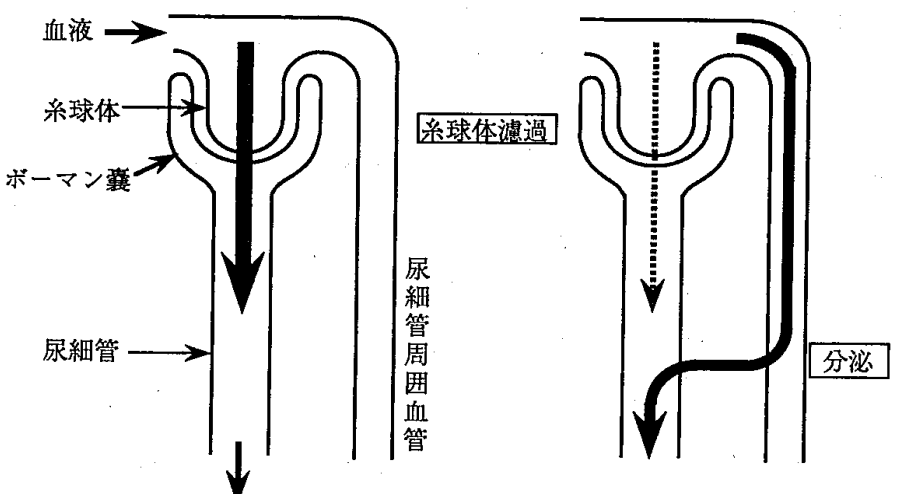

Fig. 8 腎臓機能と放射性医楽品
Tc-99m-DMSA

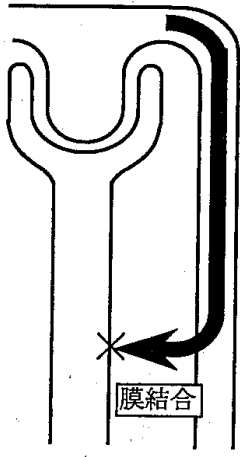


らにジエチレントリアミン五酸酸を Tc-99m 結合部位 として導入した HSA-D（前述，Fig. 4) にガラクトース 残基を導入したものが臨床に供されている。

\section{6 腎臓}

腎臟は血液から不要物を除き尿として体外に排泄する 器官であり，この過程には糸球体での水・低分子量物質 の滤過と尿細管での再吸収・分泌が含まれる.これらの 各過程に対して選択性を有する各種の放射性医薬品が開 発されている (Fig.8).

Tc-99m-ジエチレントリアミン五酶酸 (DTPA), In111-DTPA は系球体で $\mathrm{H}_{2} \mathrm{O}$ と共に濾過され再吸収を受 けないまま尿中に排泄されることから，これらの腎臟に おける時間一放射能曲線を求めることにより系球体濾過 率 (glomerular-filtration ratio，GFR）を得ることがで きる.

I-123-ヨードヒップラン (OIH) は一部は系球体濾過を 受け残りの大部分も尿細管部位で能動的に尿中分泌され るため 1 回の腎臟通過で $80 \sim 90 \%$ が尿中に移行する.し たがって尿中分泌量が腎臟に流入した血流量（rena1 blood flow，RBF あるいは renal plasma flow，RPF) の指標となる、I-123 が実用化される以前は I-131 標識 体が汎用されていた，最近，I-123-OIH と同様，尿細管

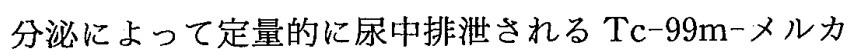
プトアセチルトリグリシン（Tc-99m-MAG3）が開発さ れ臨床検討が始められている。これらの構造を Fig. 9 に 示す。いずれも中性脂溶性部位にカルボン酸基を結合さ せたアニオン形をとっていることが特徴である。

これらとは別に腎尿細管細胞に速やかに移行した後, 尿中に排泄されることなく長時間滞留する薬郕に Tc99m-ジメルカプトコハク酸 (DMSA) がある. 臨床的に は腎皮質イメージング剤として腎臓の位置，大きさ，左 右差, 欠損の有無など形態的診断に用いられる.なお, 腎臓診断に用いられる Tc-99m-DMSA は Tc(III) の錯 体であり腫瘍診断に用いられる Tc-99m- (V)-DMS と

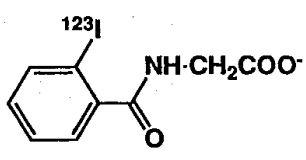

I-123-iodohipprate

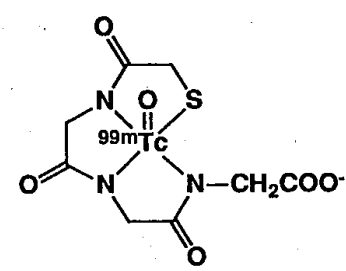

Tc-99m-mercaptoacetyltriglycine
Fig. 9 I-123-OIH おょひび Tc-99 m-MAG3 の構 造
はリガンドは同じでも錯体構造が全く異なる.

\section{7 副腎}

副腎は皮質と髄質にわかれ異なる機能を有する．皮質 においてはステロイドホルモンを合成しており基質とな るコレステロールの誘導体であるI-131-アドステロー ルが用いられる。一方，髄質においてはノルエピネフリ ンをはじめとする副腎髄質ホルモンの分泌器官であり， ノルエピネフリン類似物質であるメタヨードグアニジン (MIBG) が開発されている(現在のところ I-123-MIBG) は心筋イメージング剤としての用途が主となっている).

\section{8 脳槽}

脳脊髄液は脈絡叢で血液からつくられ脳室内を循環し た後, 脳静脈洞に戻る. 腰椎穿刺により In-111-ジエチレ ントリアミン五酶酸（DTPA）を投与すると脳脊髄液の 流れにしたがってゆっくりと脳槽に移行しやがて静脈を 経て尿中排泄される。In-111-DTPA は脳脊䯣液と同様 の生理的性質を有しなんら薬理作用を持たない点で有用 である。

\section{9 脳}

脳は, 体重の $1 / 20$ 重さを占めるのみにもかかわらず 心拍出量 (4.3〜 7.11/ $\mathrm{min})$ の $1 / 5$ から $1 / 7$ にあたる 0.8 0.91/min の血液が流れている非常に血流の豊富 な器官である。これは酸素とグルコースのみを利用し大 量のエネルギーを消費する脳の機能を維持するためにほ かならない。神経細胞は分裂せず運動もしない. したが ってこのエネルギーは基本的には神経細胞の維持と神経 活動のみに使われる。これらを前提として，脳を標的と する放射性医薬品は脳血流から脳代謝, 脳神経機能とい う方向へと進行してきている.

\section{9 .1 脳血流}

核医学における脳血流の測定には大きく分けて 2 種の 異なった原理が用いられている。

ひとつは血液脳関門を自由に拡散し脳と何ら相互作用 することなく洗いだされていく化合物を利用したもので あり, $\mathrm{Kr}-81 \mathrm{~m}, \mathrm{Xe}-133$ などの不活性ガスあるいはその水 溶液が用いられる（本邦では Xe-133の脳血流診断への 適用は未承認である).また一般的ではないが病院内サイ クロトロンを有するポジトロン核医学施設では注射液と しては O- $15-\mathrm{H}_{2} \mathrm{O}$, 吸入用ガスとしては $\mathrm{O}-15-\mathrm{CO}_{2}$ が用 いられる。 $\mathrm{O}-15-\mathrm{CO}_{2}$ は肺で炭酸脱水素酵素により速や かに O-15- $\mathrm{H}_{2} \mathrm{O}$ に変化する. これらの放射性医薬品は, 注射液として䅡動脈投与あるいはガス体として吸入投与 され, 動脈中の放射能濃度, 組織中の放射能濃度の変化 を測定することにより局所脳血流量が算出される。 


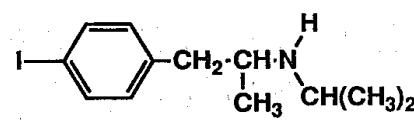

IMP<smiles>CCOC(=O)C1CSC2(NCCN2C(C)OCC)SC1</smiles>

Tc-ECD

Fig. 10 脳血流診断薬の構造

もうひとつは血流によって運ばれ脳に定量的に滞留す る性質を有する化合物を利用したものであり, $\dot{\mathrm{I}}-123$, Tc $-99 \mathrm{~m}$ など臨床利用に適した核種で標識された化合物が 開発され垁床に用いられている(Fig. 10). I-123-IMPは 覚醒アミンの脳移行性をヒントとして見いだされ，薬理 活性を示すことなく脳内に存在するアミン結合部位へ結 合する特性を有する。Tc-99m-HM-PAO は脳内に移行 後速やかに分解し水溶性錯体に変化するため膜透過性を 失い細胞内に滞留する。これらに対して, Tc-99m-ECD は，エステル部位が酵素的加水分解を受けることにより 水溶性錯体となって滞留することが報告されている。こ のように，それぞれによってもたらされる情報は血流情 報に帯留機序変化を加味したものと考えられる。したが って，それぞれの帯留性が種々疾患で不変であるかぎり においては得られる情報は血流と解釈できるが，疾患状 態により滞留性が変化する場合には血流以外の情報が含 まれることとなり薬剤間の相違も生じる可能性が考えら れる.

\section{9 .2 脳エネルギー代謝}

先にも述べたように脳はグルコーズを唯一の基質とし て酸素を必須とする好気的代謝によりエネルギーを得て いる.したがって酸素，グルコース代謝を測定すること はすなわち脳のエネルギー獲得状態を把握することに等 しい.'このような目的をもって開発されたシングルフォ トン核種標識放射性医楽品はいくつかあるが残念ながら 実用化にはいたっていない。一方，院内サイクロトロン を保有するポジトロン核医学施設においては O-15- $\mathrm{O}_{2}$ ガスによる酸素代謝測定，F-18-2-フルオロデオキシグ ルコース（FDG）による糖代謝測定が日常的に行なわれ ている。これらは定量性のある代謝データを断層画像と

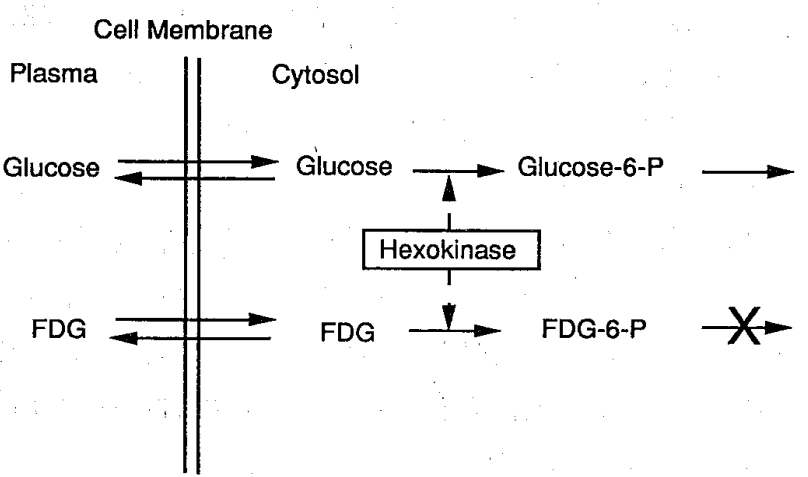

Fig.11 FDG のメタボリックトラッピング

して入手できることから高い評価を得ている。特に FDG による糖代謝測定は以下に述べるようにメタボリックト ラッピングと呼ばれる機構を利用したものであり, 特定 の酵素活性を反映する体内分布情報を得る方法として高 く評価されている。

FDG は，Fig. 11 に示すように糖代謝の第一段階とし てグルコースと同様にへキソキナーゼによるリン酸化を うけ F-18-フルオロデオキシグルコース-6-リン酸 (FDG-6-P) となるが 2 位がデオキシ化されているため にそれ以降の代謝を受けない，梼代謝の律速酵素である ヘキソキナーゼの活性に応じて FDG-6-P は細胞内に集 積 (メタボリックトラッピング) するため FDG 集積を調 べることにより糖代謝活性を評価することが可能となる。

\subsection{3 神経伝達}

脳神経細胞間における情報伝達は神経伝達物質の放出 とそれに特異的に結合し新たな細胞活動を引き起こす受 容体（レセプター）とによって行なわれる。神経紼胞は このような物質のやりとりを效率よくかつ選択的に行な うために，信号を伝達するべき細胞に向かって突起を長 く延ばしシナプスと呼ばれる接合部を形成する.シナプ スは一つの神経細胞に数十から数千あり複雑な神経回路 網を構成する，神経伝達物質は, 突起の接合部分（プレ シナプス）から分泌されレセプターを有する細胞の接合 部分（ポストシナプス）に到達し結合する。結合しなか つた神経伝達物質は分解されるか再度利用されるために プレシナプスに吸収される。このような神経情報伝達の 過程を画像化する目的で種々の原理に基づく放射性医薬 品が提案されている，レセプタ一結合能を有する薬物に は，結合して本来の神経伝達物質と同様の作用を発揮す るアゴニストと, 結合はするが作用を発揮しないアンタ ゴニストとがある。一般にはアンタゴニストの放射能標 識体が用いられることが多い。レセプター結合を集積機 序とする放射性薬郕を Table 3 に列挙する。これとは別 
Table 3 脳のレセプターを標的とする放射性医薬品

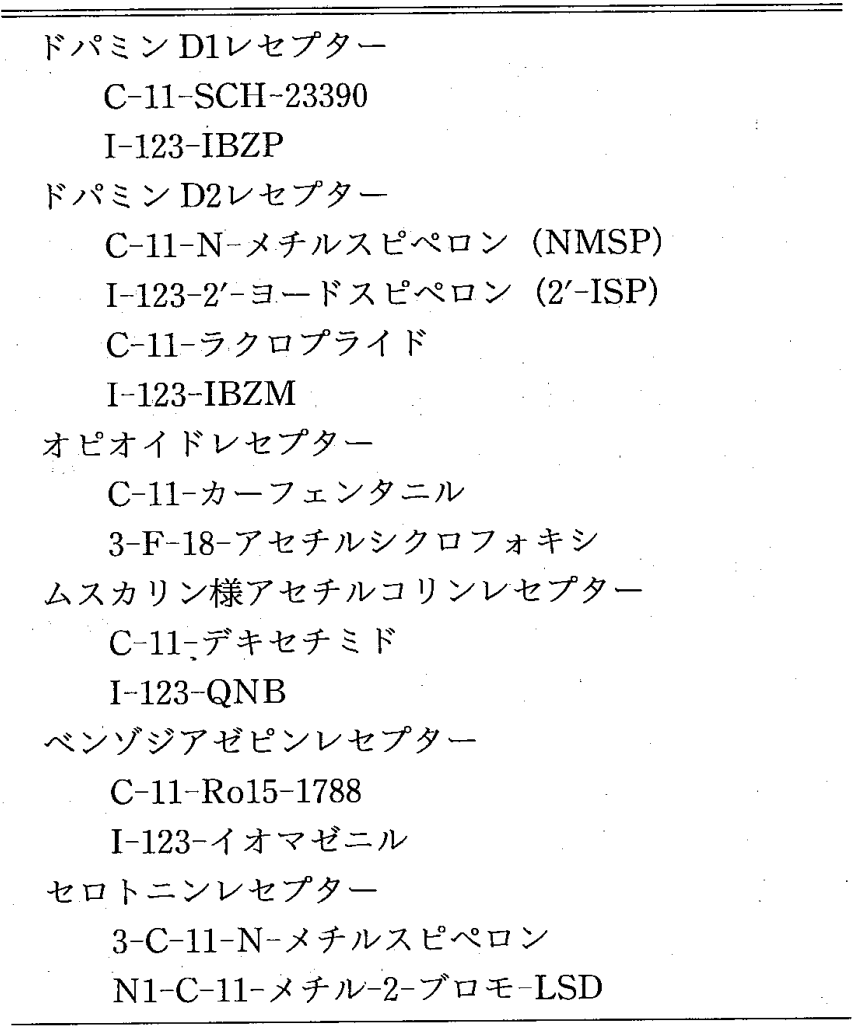

Table 4 神経伝達機能の測定に用いられる放射性 医薬品

\begin{tabular}{ll}
\hline \hline \multicolumn{1}{c}{ 薬冎 } & \multicolumn{1}{c}{ 測定される機能 } \\
\hline $\mathrm{F}-18-$ フルオロドパ & ドパミン貯蔵量 \\
$\mathrm{C}-11-$ デプレニル & モノアミン酸化酵素活性 \\
$\mathrm{I}-123-\alpha$-メチルチロシン & 脳血管・神経細胞アミノ酸輸送 \\
\hline
\end{tabular}

にプレシナプス機能を評価する目的で神経伝達物質の再 吸収，あるいは神経伝達物質合成前躯体の取り込みを画 像化する薬剤も開発されている (Table 4).

しかしながら，これらの多くは院内サイクロトンを必 要とするポジトロン標識体であり，シングルフォトン核 種標識体についても一般に利用できるものは非常に限定 されているのが実状である．本邦で企業供給を前提に臨 床検討が始められている薬剮としてはベンゾジアゼピン レセプターを画像化する I-123-イオマゼニルがある。べ ンゾジアゼピンレセプターはてんかん患者脳で減少して いることが知られ痴呆などでも変化することから, 従来 の診断では発見できなかった脳の変化を検出できるので はと期待がもたれている.

\subsection{0 心 臓}

心臟核医学で行なわれている検查は，心筋血流，心機 能，エネルギー代謝，神経機能，心筋梗塞イメージング

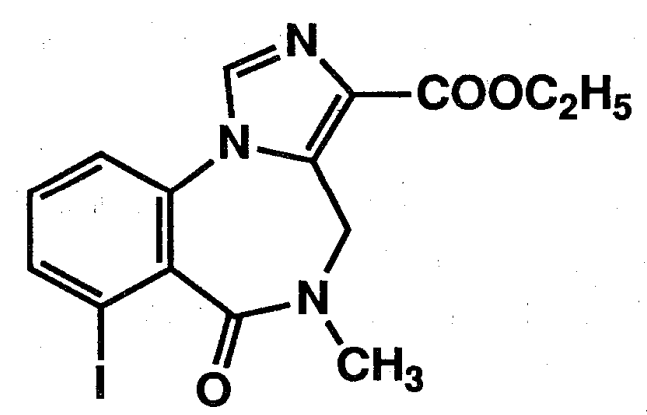

Fig. 12 イオマゼニルの構造

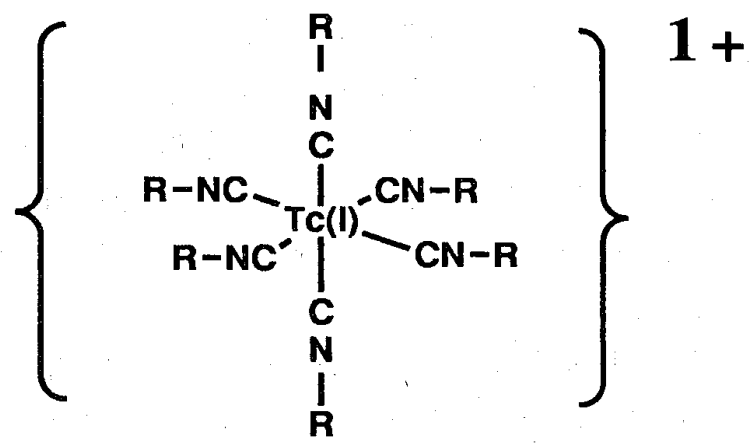<smiles>[R]#CCC(C)(C)OC</smiles>

Fig. 13 Tc-99 m-MIBI の構造

である.

4.10 .1 心筋血流

心筋血流の評価は, 血流に依存して心筋に移行し定量 的に滞留する性質を有する放射性医薬品を用いる．この ような目的でもっとも沉用されているのはT1-201-塩化 タリウムである. T1-201はカリウム類似の1 価カチオン であり $\mathrm{Na} ， \mathrm{~K}$-ポンプに親和性を有することから一部は 能動輸送により心筋に高く集積する.T1-201 は心筋血流 診断薬剤として臨床的に非常に重要な地位を占めている. しかしながら T1-201の $\gamma$ 線エネルギーが低く Tc-99m 等に比べて明瞭な画像を得にくいことから，これに替わ る Tc-99m 標識製郕の開発が行なわれ，Fig. 13 に示す Tc-99m-MIBI などが開発供給されている.Tc-99mMIBI は全体として 1 価カチオンの電荷をもつ脂溶性錯 体であるがその集積機序は T1-201とは若干異なり能動 輸送によらないことが示されているなど，そのもたらす 情報が Tl-201と全く同じとは考皃にくい.したがってこ れらの Tc-99m 標識製剂を血流診断薬剤として利用す るにあたっては, 単に Tl-201の代替として評価するので 
はなく新しい製剤として改めて臨床意義を評価する必要 性が生じる可能性は高い.

\subsection{0 .2 心機能}

心臓のポンプとしての機能測定は，標識血液成分（前 述)を用いて循環時間, 指出量, 壁運動, 先天的奇形(壁 欠損等）の検出が行なわれる．詳細は別書にゆずる.

\subsection{0 .3 エネルギー代謝}

心筋は, 脂肪酸, グルコース, 乳酸などをエネルギー 源として活発に代謝を行なっている。しかも正常空腹時 には必要なエネルギーのほとんどを脂肪酸 $\beta$ 酸化によ り獲得するのに対し，食後高血糖時にはグルコースを利 用するようになり，虚血により酸素久乏になると，解糖 系，嫌気性代謝を行なうなど多様な変化に対応している 組織である．したがって心筋のエネルギー状態を把握す ることは心筋のおかれている状況を判断するうえで非常 に有用である。

$\mathrm{C}-11$ 標識脂肪酸である1-C-11-パルミチン酸は，心筋 に取り込まれた後 $\beta$ 酸化を経て炭酸ガスにまで代謝さ れ心筋から洗いだされる。したがってその集積と洗い出 しを経時的に追跡することにより心筇 $\beta$ 酸化機能を測 定することができる，しかしながらこの検査は院内サイ クロトロンを必要とする上に煩雑な手技が必要なため広 く普及するには問題が多い。このような点を改善する目 的で， $\beta$ 位にメチル基を導入しかつ標識核種として I123を用いた脂肪酸誘導体（BMIPP，Fig. 14）が開発さ れ市販されている. BMIPP は, 脂肪酸として心筋に取り 込まれトリグリセリド脂質プールにまでは入るが $\beta$ ーメ チル基導入により $\beta$ 酸化が起きないため長時間にわた つて心筋内に貯留する性質を有する。これら一連の BMIPP の挙動は脂肪酸代謝のある部分を反映している 点は事実であるが $\beta$ 酸化そのものを評価しているわけ ではないためその意義づけについては今後の臨床データ の蓄積が必要であろう。いずれにしてもこの性質は測定 に時間を要する SPECT に適したものであり利用しやす さともあいまって今後の普及が期待される。

心筋グルコース代謝は, FDG を用いて行なわれる.特 に，虚血心筋におけるグルコース代謝の元進はこの検査 法がもっとも感度よく検出できるためその意義は大きい.

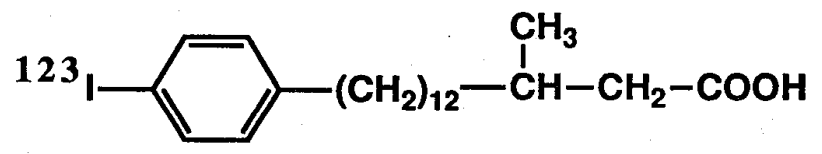

Fig. 14 BMIPP の構造
広範な利用についてはFDG の企業的供給が待たれる。 脂肪酸，グルコースを問わず好気的代謝においてはク レブス回路 (TCA 回路) でATP が産生される。この過 程を直接測定する目的で C-11-酢酸が合成されている。

\subsection{0 .4 神経機能}

心筋を支配している交感神経機能を評価することを目 的として交感神経終末においてノルエピネフリン貯蔵顆 粒に取り込まれる性質を有する I-123-MIBG（副腎の項 参照）が用いられている．神経は心筋組織に比較して虚 血に弱いとされ，虚血発生歴の鋭敏な指標として期待さ れている。

\subsection{0 .5 心筋梗塞}

骨イメージング剤である Tc-99m-ピロリン酸が心筋 梗塞部位に集積することが知られ，利用されている．特 に急性期に高い集積の機序は明確ではないが，障害心筋 に生じるカルシウム沈着との関連が指摘されている。こ れとは別に，障害心筋において収縮タンパクであるミオ シンが露出することを利用して標識抗ミオシン抗体によ る障害心筋イメージングが臨床的に試みられ良好な結果 を得ている。

\subsection{1 腫瘍}

現在臨床に用いられている放射性医薬品は，経験的に 多くの種類の腫湟に集積することが見いだされ特異性は 低いが転移を含め位置の特定に有用なものと，特定の機 能を持つ腫瘍のみを標的としてデザインされた選択性の 高いものとに分類できる。

Ga-67-クエン酸ガリウムは最も広く用いられている 放射性医薬品である。しかしながらその腫瘍集積機序に はいまだ議論がある．現在広く受け入れられている提案 としては，静脈内投与された Ga-67が血液中でトランス フェリンと結合しさらに腫湯細胞膜表面のトランスフェ リンレセプターと作用して腫瘍内に取り込まれるという ものがある.一方，Ga-67-クエン酸の多核錯体としての 化学的性質が腫瘍集積に関与しているのではないかとの 議論もなされている。いずれにしても悪性腫湯組織，特 に乳癌，肺癌，悪性リンパ腫などへ高い集積を示しその 臨床的価值は非常に高いものがある。しかしながら，Ga -67-クエン酸ガリウムは炎症などにも集積することが知 られており，腫瘍と炎症との鑑別に際しては注意が必要 である。T1-201-塩化タリウムは心筋イメージング剂と して開発されそのカリウムイオン類似性が集積機序に関 与し血流に応じた心筋集積をするが，腫瘍においてもカ リウム含量が高く血液供給の豊富な甲状腺腫, 副甲状腺 腫，肺癌；子宮癌などに集積する。 
特定の代謝機能あるいは構造を有する腫場を標的とし て開発，利用されているものがある.

I-123-ヨウ化ナトリウムは甲状腺に集積すると同様の 機序により甲状腺ホルモン産生腫湯に集積する。また Tc-99 m-Tc (V)-DMS は, DNA 合成艺進にともなうリ ン酸集積増加の検出を目的として $\mathrm{TcO}_{4}{ }^{3-}$ とリン酸イオ ンとの類似性を利用してデザインされた放射性医楽品で, 主として甲状腺髄様癌などに高い集積を示す。この薬剤 は本邦で開発されながら市販されるに到らずヨーロッパ などで広く利用され始めている．副腎髄質診断のところ で述べた I-123-MIBG，I-131-MIBG は，副腎髄質と同 様カテコールアミン代謝の盛んな副腎腫瘍, 褐色細胞腫, 神経芽細胞腫の診断にも用いられる。

腫湟細胞の活発な代謝を検出するポジトロン放射性医 楽品としてF-18-フルオロデオキシグルコース (FDG)，C-11-メチオニンなどがある. 特に FDG は脳， 心筋で述べたようにメタボリックトラッピングによる局 所糖代謝測定に用いられ, 腫崵の性質を精代謝率を指標 として評価する診断薬剤として悪性度や治療効果判定へ の寄与が期待されている。

抗原一抗体反応は特異性と感度に優れ, これを利用した 腫湟関連抗原検出がインビトロ検查の中で重要な地位を 占めていることは周知のとおりである。これをインビボ 核医学に利用し標識抗腫瘍抗体による腫瘍組織の検出・ 同定が試みられている。実用化にあたつてはいくつかの 問題があり現在のところ臨床研究の段階ではあるが, イ ンビボ核医学への標識抗体の適用は標識抗ミオシン抗体 による障害心筋診断に関する検討によってもかなり認知
されてきており今後の展開に期待がもたれる.

\section{5. 調製・品質管理}

放射性医薬品も基本的には一般薬と同様, 薬事法によ る規制をうけるが，その特殊性からさらに放射性医薬品 基準などの独自の製剤総則，一般試験法が規定されてい る. 医療現場でこれらに直接出会うことは少ないが, 放 射性医薬品は短寿命であるため企業供給とともに臨床現 場で使用時に調製されるものも多く, 調製法や品質管理 については調製者自身が行なえる技術と知識を身に付け ることが望ましい，特にキット化された製蝺の標識反応 は金属の錯体形成反応を利用したものがほとんどであり 迅速かつ多様な反応である点が特徵である．このことは わずかな操作の相違が全く異なる化学形をもたらす可能 性があることを示しており注意が必要である。いずれに しても，序諭に述べたように核医学検査情報は用いられ る放射性医薬品の是非によってすべてが決まってしまう ことを念頭においた管理が望まれる.

\section{参考文献}

1）放射性同位元素等による放射線障害の防止に関する 法令集，社日本アイソトープ協会編，丸善書店.

2）放射性医楽品一覧表, 社日本アイソトープ協会編 集・発行.

3）アイソトープ手帳，社日本アイソトープ協会編集・ 発行.

4) 放射化学 - 放射薬品学, 小嶋正治, 杉井 篤, 久保 寺昭子編, 南江堂. 